\title{
Effect of the Slurry Application Method on Odour Emissions: A Pilot Study
}

\author{
Wojciech Rzeźnik ${ }^{1 *}$, Paulina Mielcarek-Bocheńska ${ }^{2}$ \\ 'Poznan University of Technology, Institute of Environmental Engineering, Poznan, Poland \\ ${ }^{2}$ Institute of Technology and Life Sciences, Falenty, Raszyn, Poland
}

Received: 20 November 2018

Accepted: 14 April 2019

\begin{abstract}
The sustainable intensification of agriculture needs the use of natural fertilizers. Odour emission from their application is bothersome for the surroundings - especially in suburban areas. The aim of the study was to compare odour concentrations after pig slurry application using two different types of applicators. Odour measurements were carried out on two experimental fields where the pig slurry was applied by different methods. On field I it was a trailing hose applicator (Zunhammer SKE 15,5), and on field II it was a conventional splash-plate applicator (Joskin Modulo 28400 with a so-called 'Exact' scatterer). Measurements included 6 series in the following periods: immediately after application and 1 , 2, 3, 4 and 5 hours after application. Odour analysis was made within $30 \mathrm{~h}$ of collection using the dynamic olfactometry method (ECOMA TO 8 olfactometer) according to the Standard PN-EN 13725:2007. The average value of odour concentration was $683 \mathrm{ou}_{\mathrm{E}} \cdot \mathrm{m}^{-3}$ for a trailing hose applicator and $522 \mathrm{ou}_{\mathrm{E}} \cdot \mathrm{m}^{-3}$ for conventional splash-plate applicator. Three hours after application of pig slurry, the odour concentrations on two experimental fields were relatively low and almost did not differ between each other. Use of the trailing hose applicator for pig slurry application resulted in $31 \%$ higher odour emissions than slurry spreading by conventional splash-plate applicator. The biggest difference between odour concentration was immediately after application $(56 \%)$ and it decreased to almost $0 \%$ (3 hours after application). The largest decrease in odour concentration, by nearly $50 \%$ for both fields, was observed during the first hour after slurry application.
\end{abstract}

Keywords: odour emission, odour concentration, slurry application, trailing hose applicator, slurry spreading

\section{Introduction}

Population growth together with the increase in the standard of living forces modern agriculture to

*e-mail: wojciech.rzeznik@put.poznan.pl

supply more and more products at relatively low prices. This leads to the intensification and concentration of agriculture - especially livestock production. Although intensive farming successfully implements economic goals, it may also cause negative environmental effects. The increased use of fertilizers, plant growth regulators and protection products (pesticides) raises the public's concerns about the quality of products, consumer health 
and environmental protection [1]. The answer to potential threats is sustainable intensification, which means increasing yields by improving economic efficiency, limiting negative impact on the environment and caring for food quality. One of the elements of sustainable intensification is the use of natural fertilizers, which are a valuable source of nutrients for plants as they enrich the soil with humus and improve its physical, chemical and biological properties [2, 3].

Almost all of the natural fertilizers produced in Poland are used on agricultural lands. In the 2015/2016 marketing year, 50 million tons of solid manure were applied to 3.1 million ha and 20.8 million cubic meters of liquid manure and slurry to 1.2 million ha [4]. Their use limits the mineral fertilization, but it also causes the emission of gaseous pollutants. Many strategies have been developed to reduce harmful gas emissions at all stages of manure management. The field application has been identified as a process where these emissions are relatively large, but quite easy to reduce [5]. The application of natural fertilizers causes not only harmful gas emission, but it is also the source of unpleasant odours - especially in the case of slurry [6]. Studies showed that long-term exposure to odours adversely affects the mood and behaviour of people. It was found that they may cause many ailments, such as insomnia, stress, apathy, irritability, depression, headache, cough, runny nose, cramps in the chest and allergic reactions $[7,8]$. Odour emissions from their application is considered as more onerous for surroundings than from livestock housing $[9,10]$. A confirmation of which is the large number of complaints on odour nuisance from natural fertilization [11]. This is especially noticeable in suburban areas where agricultural lands are transformed into residential and industrial areas [12].

So far, the main direction of the modification and developing new methods and devices for the land application of natural fertilizers was the reduction of ammonia $\left(\mathrm{NH}_{3}\right)$ and nitrous oxide $\left(\mathrm{N}_{2} \mathrm{O}\right)$ emissions. These solutions primarily reduced the time of contact between natural fertilizers and air by their covering by soil shortly after application in the field or their application directly into the soil [13-16]. Duncan at al. [13] noted that using shallow disk manure injection reduced $\mathrm{NH}_{3}$ emissions by $92-98 \%$. Whereas Pote and Meisinger [17] applied the manure below the soil surface using the 'Subsurfer' prototype and observed about $88 \%$ reduction of $\mathrm{NH}_{3}$ emission. Also, the trailing hose method is a good practise to reduce ammonia emissions. Personne et al. [18], Häni et al. [19], and Döhler et al. [20] noted reduction ranging from 30 to $51 \%$ compared to the broadcast application. There are few studies about the impact of application methods of natural fertilizers on odour emissions, and the results are not unambiguous.

In Poland, the most popular is the surface land spread of slurry, mainly because of lower purchase and operating costs compared with other methods. Meeting the EU reduction levels of pollutant emissions into the atmosphere and the increase of environmental awareness results in the use of trailing hose applicators on a wider scale. This method is a compromise between slurry application costs and environmental effects and it may be obligatory in the future.

The aim of our study was to compare odour concentrations after pig slurry application using two different types of applicators: a trailing hose and a conventional splash-plate.

\section{Materials and Methods}

Odour measurements were carried out at a private farm in Szczytniki Czerniejewskie (Greater Poland Province) in March 2017 that included two experimental fields $180 \times 24 \mathrm{~m}$. The distance between them was $350 \mathrm{~m}$ (Fig. 1). The wind direction during test was parallel to the long side of the experimental fields, which minimize the mixing of air from both fields.

The experimental fields were in an area planed for maize. Pig slurry was applied on the surface of experimental fields using two different methods and devices. On field I it was trailing hose applicator (Zunhammer SKE 15,5). The distance between hoses was $0.3 \mathrm{~m}$ (Fig. 2).

On experimental field II the slurry was spread by a conventional splash-plate applicator (Joskin Modulo

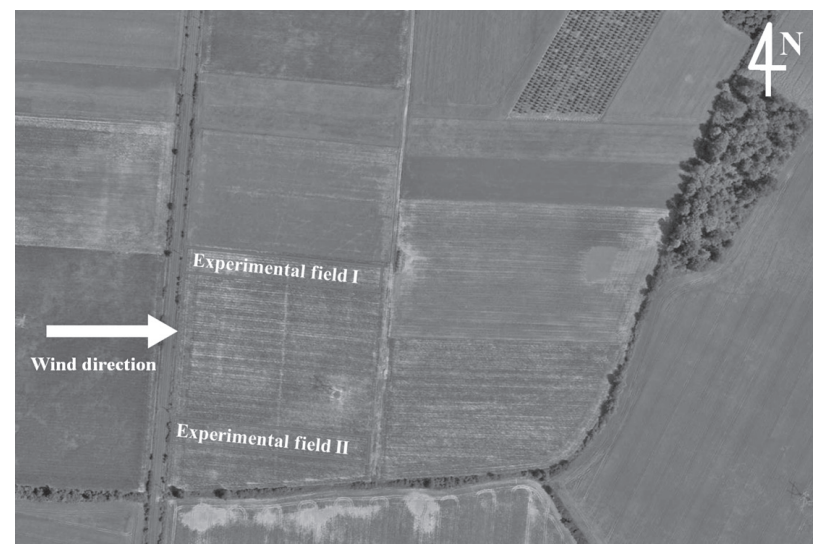

Fig. 1. Experimental fields..

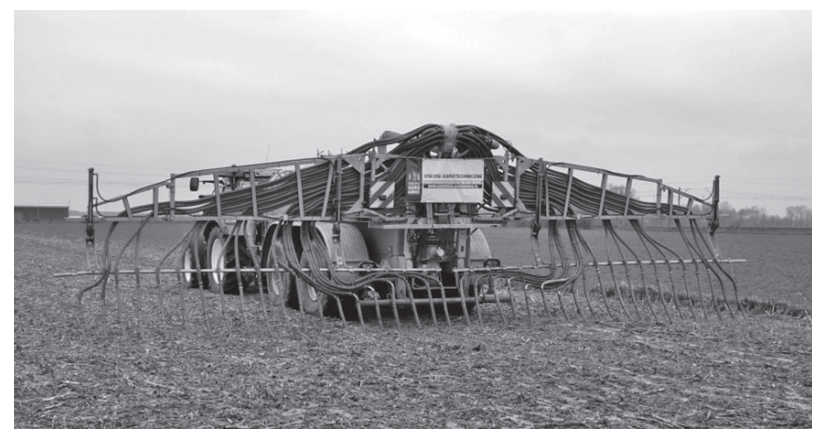

Fig. 2. Trailing hose applicator - experimental field I. 


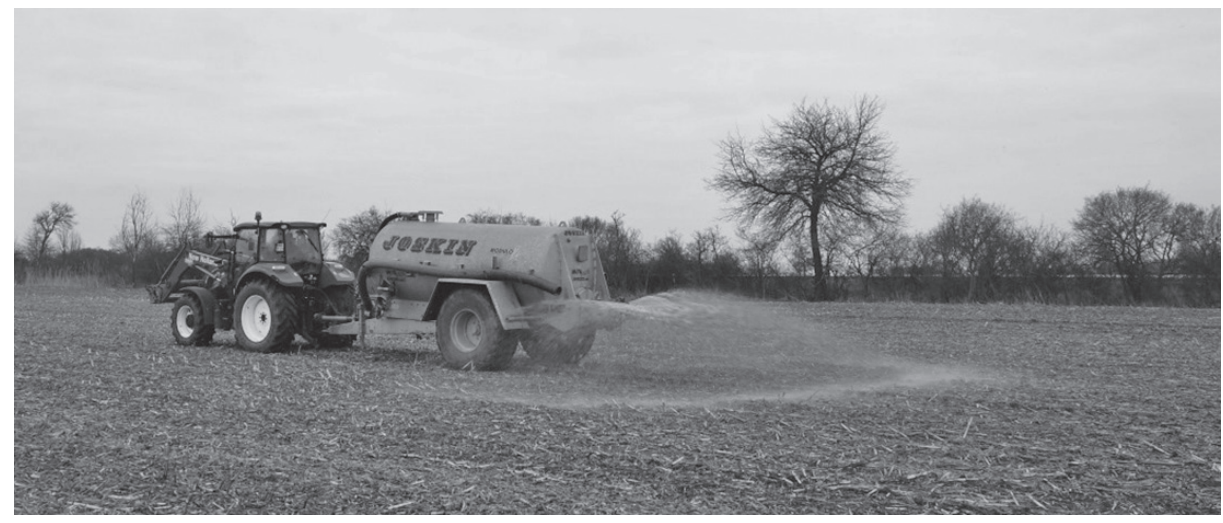

Fig. 3. Conventional splash-plate applicator - experimental field II.

28400 with a so-called 'Exact' scatterer). Using this method, slurry was evenly distributed over the whole field surface. The slurry dose was the same for both experimental fields $-20 \mathrm{~m}^{3} \cdot \mathrm{ha}^{-1}$.

The odour emission decayed exponentially with time, so high rates of emission during the first few hours were observed. The sampling time was taken on the basis of published papers [21-23] and our own observations during a study on odour emissions from solid manure and biogas digestate land application [24, 25]. In most of the analysed studies there was no swine slurry odor evident at $6 \mathrm{~h}$. Therefore, these measurements included 6 series in the following periods: immediately after application and 1, 2, 3, 4 and 5 hours after application.

The pig slurry came from the fully-slatted piggery. Its physicochemical parameters are presented in Table 1.

Before air sampling for olfactometric analysis, selected parts of the experimental fields were covered. The chambers used for sampling air from surface sources were in accordance with the VDI 3880:2011 standard (Fig. 4).

The sampling time of one sample was 5 minutes. Odour samples were collected by a CSD30 sampler (ECOMA) to 8-1 disposable Nalophan (PET) bags. This minimized the diffusion of pollutants from the bags into the air and thus change in the chemical composition of the sample between the collection and analysis

Table 1. Physicochemical parameters of slurry.

\begin{tabular}{|c|c|}
\hline Parameter & Value \\
\hline $\mathrm{pH}$ & 7.42 \\
\hline Dry matter & $6.2 \%$ of fresh matter \\
\hline Dry organic matter & $76.4 \%$ of dry matter \\
\hline Ash & $23.6 \%$ of dry matter \\
\hline Nitrogen content & $5900 \mathrm{mg} \cdot \mathrm{dm}^{-3}$ \\
\hline Phosphorus content & $1050 \mathrm{mg} \cdot \mathrm{dm}^{-3}$ \\
\hline Potassium content & $3.52 \%$ of dry matter \\
\hline
\end{tabular}

was also limited. Then samples were transported to an olfactometric laboratory accredited by the PCA (Polish Centre for Accreditation) and located at the Institute of Technology and Life Sciences in Poznań. The odour analysis was made within $30 \mathrm{~h}$ of collection. The dynamic olfactometry method (ECOMA TO 8 olfactometer) was used according to the Standard PNEN 13725:2007.

Based on the odour concentrations, their distributions in time were made. It was described by regression equations $C_{o}(t)$. The average odour concentration $\left(C_{a v}\right)$ was calculated using the equation below:

$$
C_{a v}=\frac{1}{t} \int_{0}^{5} C_{o}(t) d t
$$

...where:

$C_{o}(t)$ - the equation of the relationship between the concentration of odours and time

$t$ - time

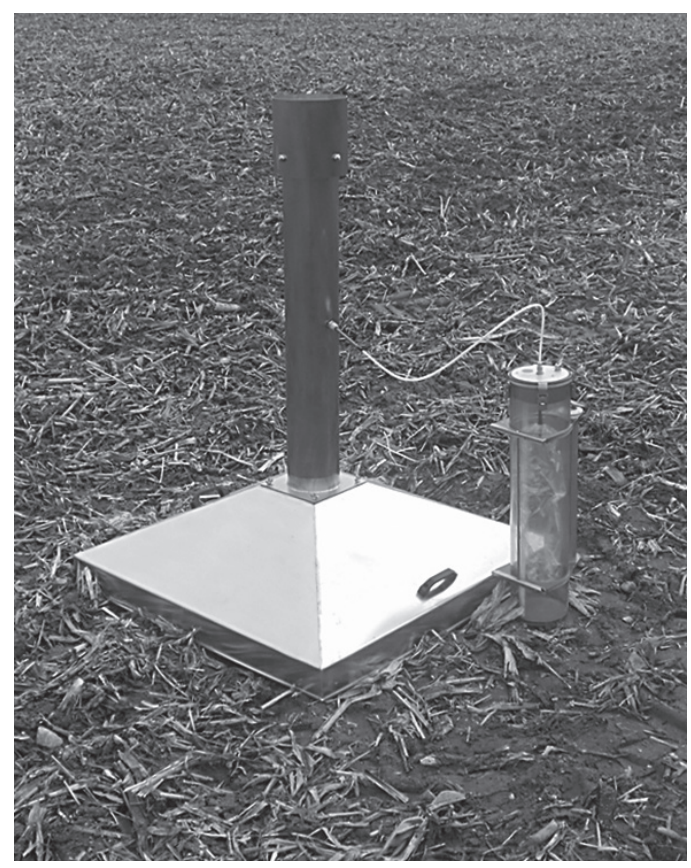

Fig. 4. Sampling chamber. 


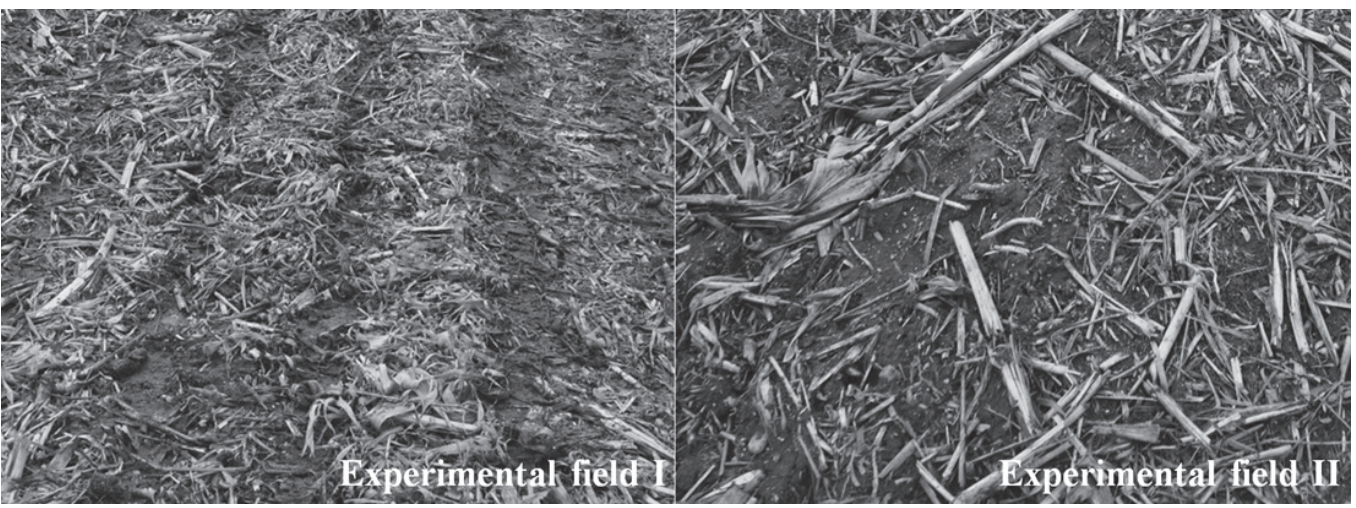

Fig. 5. The surfaces of experimental fields after application of slurry..

The experimental fields, except sampling time, were uncovered, so it was assumed that the air exchange was the same for both experimental fields. Given this assumption, the differences in odour emissions, expressed in percentage, resulting from the slurry application methods are the same as differences in the odour concentrations on the experimental fields.

During the air sampling, the temperature and relative humidity of the air were also measured by the multifunctional Testo 435-4 measuring instrument (accuracy: $0.3^{\circ} \mathrm{C}$ and $2 \%$ ).

\section{Results and Discussion}

Fig. 5 shows the surface of the experimental fields after slurry application. On field I, the slurry was applied in rows, while on field II it covered the whole surface evenly.

The values of the determined odour concentrations as well as the temperature and relative humidity of air during sampling are presented in Table 2.

For three hours after the slurry application, a higher concentration of odours was observed on experimental field I, where a trailing hose applicator was used. The difference of odour concentration decreased from $56 \%$ (immediately after application) to $0 \%$ (3 hours after application). Later, the odour concentrations on two fields were relatively low and almost did not differ between each other. The largest decrease in odour concentration, by nearly $50 \%$ for both fields, was observed during the first hour after the slurry application. Similar results were noted by Feilberg et al. [26], who found that the main odorous substances were released within the first 10-20 minutes after application. It was also observed by Hellstedt and Haapala [27] during measurement of odour concentration using a Nasal Ranger portable olfactometer after slurry spreading. They noted that 60 minutes after application, the relative odour concentration decreased to almost 0 , while Parker et al. [23] measured odorous volatile organic compounds (VOC) emissions following surface broadcast application of slurry and they observed that VOC emission rates declined rapidly after land application, and were below levels of detection and near background levels within 4 to $8 \mathrm{~h}$. Hanna et al. [22] compared odour concentrations on two fields at different times of the year: first after soybean cultivation and the second after maize cultivation. For application, they used a conventional splash-plate applicator. The odour concentration after slurry spreading ranged from $140 \mathrm{ou}_{\mathrm{F}} \cdot \mathrm{m}^{-3}$ to $1451 \mathrm{ou}_{\mathrm{F}} \cdot \mathrm{m}^{-3}$ for soybean stubble, and from $183 \mathrm{ou}_{\mathrm{E}} \cdot \mathrm{m}^{-3}$ to $1604 \mathrm{ou}_{\mathrm{E}} \cdot \mathrm{m}^{-3}$ for maize stubble. Significantly lower values of odour concentrations 19-70 $\mathrm{ou}_{\mathrm{E}} \cdot \mathrm{m}^{-3}$, after slurry application using the same method, but on light soils, were given by Smith et al.

Table 2. Odour concentration, air temperature and relative humidity during study.

\begin{tabular}{|c|c|c|c|c|c|c|}
\hline \multirow{2}{*}{$\begin{array}{l}\text { Sampling } \\
\text { time }\end{array}$} & \multicolumn{3}{|c|}{ Experimental field I } & \multicolumn{3}{|c|}{ Experimental field II } \\
\hline & $\begin{array}{c}\text { Temperature } \\
\left({ }^{\circ} \mathrm{C}\right)\end{array}$ & $\begin{array}{l}\text { Relative humidity } \\
\text { (\%) }\end{array}$ & $\begin{array}{l}\text { Odour concentration } \\
\qquad\left(\mathrm{ou}_{\mathrm{E}} \cdot \mathrm{m}^{-3}\right)\end{array}$ & $\begin{array}{c}\text { Temperature } \\
\left({ }^{\circ} \mathrm{C}\right)\end{array}$ & $\begin{array}{l}\text { Relative humidity } \\
(\%)\end{array}$ & $\begin{array}{l}\text { Odour concentration } \\
\qquad\left(\mathrm{ou}_{\mathrm{E}} \cdot \mathrm{m}^{-3}\right)\end{array}$ \\
\hline 0 & 9.8 & 76.3 & 1666 & 10.1 & 75.7 & 1067 \\
\hline 1 & 12.9 & 64.3 & 862 & 12.7 & 58.1 & 553 \\
\hline 2 & 13.8 & 69.3 & 632 & 13.4 & 61.8 & 485 \\
\hline 3 & 13.2 & 68.7 & 466 & 13.3 & 61.6 & 466 \\
\hline 4 & 14.1 & 66.3 & 445 & 13.8 & 62.4 & 444 \\
\hline 5 & 13.9 & 67.5 & 302 & 14.3 & 63.4 & 245 \\
\hline
\end{tabular}


[28]. Similar results were reported by Chen et al. [29]. They compared two methods: broadcast application and direct manure injection. The average odour concentrations right after manure application were $61 \mathrm{ou}_{\mathrm{E}} \cdot \mathrm{m}^{-3}$ and $44 \mathrm{ou}_{\mathrm{E}} \cdot \mathrm{m}^{-3}$, respectively, but the air samples to odour measurement were collected without using the measurement chamber. Agnew et al. [5] in their studies measured the odour concentration after the surface spreading of slurry and the mean value was $641 \mathrm{ou}_{\mathrm{E}} \cdot \mathrm{m}^{-3}$. In turn, Chen et al. [30] during their research used a trailing hose applicator on grasslands and the average odour concentration after slurry application amounted to $1094 \mathrm{ou}_{\mathrm{E}} \cdot \mathrm{m}^{-3}$. Orzi et al. [31] analyzed odour concentration after slurry spreading and they noted values of 3404-4305 $\mathrm{ou}_{\mathrm{E}} \cdot \mathrm{m}^{-3}$. Very high concentrations of odours $-39000 \mathrm{ou}_{\mathrm{E}} \cdot \mathrm{m}^{-3}$ were measured by Lau et al. [32]. The samples were collected at the time of slurry spreading. In the same work, the preliminary results indicated that with the sub-surface deposition system applicator odour emission rate was reduced by $8 \%$ to $38 \%$ compared to that of the conventional splash-plate applicator. The highest reduction in odour strength and odour emission rate was observed in the most offensive period after manure application.

Figs 6 and 7 show the distribution of odour concentrations on experimental fields, which were described using exponential equations. The regression

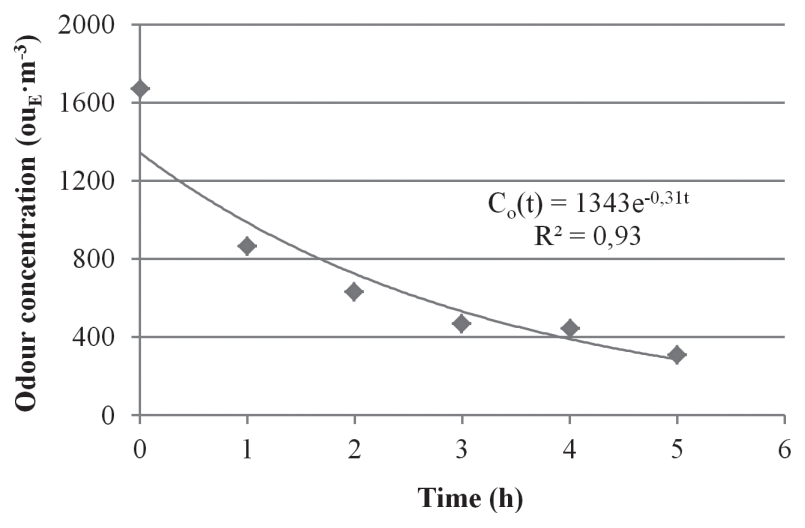

Fig. 6. Odour concentration on experimental field I.

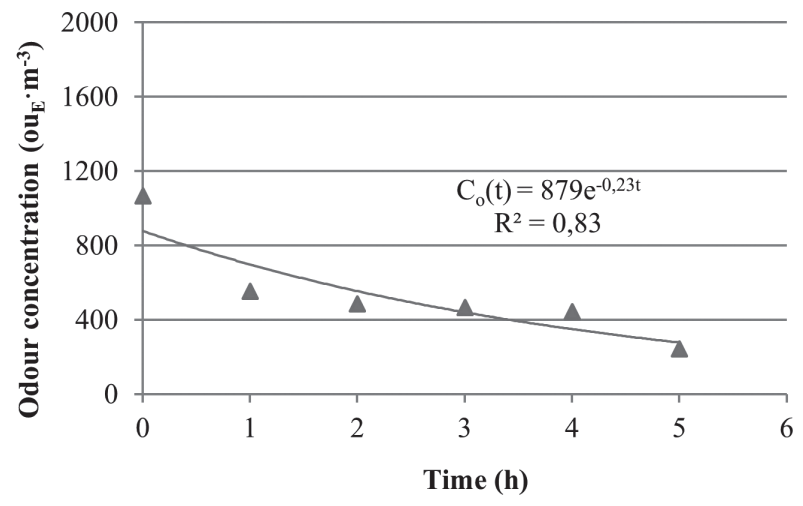

Fig. 7. Odour concentration on experimental field II. equations in $93 \%$ (for field I) and $83 \%$ (for field II) match the data obtained in the research.

The average value of odour concentration was calculated according to Equation (1), which was $683 \mathrm{ou}_{\mathrm{E}} \cdot \mathrm{m}^{-3}$ for experimental field I (trailing hose applicator) and $522 \mathrm{ou}_{\mathrm{E}} \cdot \mathrm{m}^{-3}$ for experimental field II (conventional splash-plate applicator). Based on these values, it was determined that slurry application by the trailing hose applicator caused about 31\% higher odour emissions than the conventional splash-plate applicator. The slurry spreading by conventional splashplate applicator creates small droplets of slurry, whose contact time with the air is longer than in the case of the trailing hose applicator. This may entail a sudden release of odours before the slurry falls to the ground. Moreover, covering the field with slurry on the entire surface may cause both the intensive release of odorants just after the application and faster percolating of slurry into the soil. After application by trailing hose applicator, the slurry stay on a field's surface in rows, which extends percolating time so that the odour may release over a longer period of time. Moseley et al. [33] did not observe differences in odour emissions between the trailing shoe applicator and slurry spreading. Agnew et al. [5] noticed that replacing slurry spreading by the slurry incorporation to the soil caused a $12 \%$ reduction in odour emissions. Hanna et al. [22] compared the conventional pig slurry spreading with five techniques of slurry incorporation. They observed that slurry incorporation techniques reduced odour emission by 20 to $90 \%$ depending on the technique, compared to slurry spreading. They also noted that the odour concentration quickly decreased in time. Often already in the day of application it did not differ from the odour concentration on the non-fertilized field. Riva et al. [34] measured odour emissions after the application of digestate by two methods: broadcast and injection application. They observed a $13.4 \%$ odour emission reduction during digestate fertilization by injection. The same two methods of application were compared by Orzi et al. [31], who noted that switching from surface to injection methods led to the reduction of odour impact by $50-74 \%$.

\section{Conclusions}

The results of the pilot study showed that using a trailing hose applicator resulted in $31 \%$ higher odour emissions than slurry spread by a conventional splashplate applicator. The biggest differences between odour concentrations appeared immediately after application $(56 \%)$ and decreased to almost $0 \%$ (3 hours after application). The largest decrease in odour concentration - by nearly $50 \%$ for both fields - was observed during the first hour after the slurry application.

In order to complete the odour evaluation of these methods of slurry application, it was also necessary to measure concentrations and emissions of odours during 
application - before the natural fertilizer fell to the field. Research on methods of manure and slurry application should be continued, but during the multi-criteria tests in order to provide comprehensive assessment of the tested technique. Such studies should include many aspects, for example: quality of fertilizing, ammonia emission, GHG emission, the release of odours, economic efficiency and influencing factors like the season, soil type, land use and type of natural fertilizer. It appears that surface slurry applicators that do not directly incorporate the manure are not as effective at reducing off-ending odours. So taking into account environmental and agronomical benefits, future studies should focus on direct injection or rapid incorporation, which seem to be effective practices for mitigating odour emission.

\section{Acknowledgements}

Our work was co-financed by the Ministry of Agriculture and Rural Development and carried under the Multiannual Program for the years 20162020: "Technological and environmental projects for innovative, effective and low-emission economy in rural areas."

\section{Conflict of Interest}

The authors declare no conflict of interest.

\section{References}

1. SOBCZYŃSKI T. Intensification and Concentration of Production and Environmental and Economic Sustainability of Dairy Farms and Specialist Granivores in the EU. Annals of The Polish Association of Agricultural and Agribusiness Economists. 13 (4), 154, 2011 [In Polish].

2. BEDDINGTON SIR J. The future of food and farming. Int. J. of Agric. Manage. 1 (2), 2, 2011.

3. TOKBERGENOVA A., KIYASSOVA L., KAIROVA S. Sustainable Development Agriculture in the Republic of Kazakhstan. Pol. J. Environ. Stud. 27 (5), 1923, 2018.

4. STATISTICS POLAND. Means of production in agriculture in the 2015/2016 farming year. Available at http://stat.gov.pl/obszary-tematyczne/rolnictwo-lesnictwo/ rolnictwo/srodki-produkcji-w-rolnictwie-w-rokugospodarczym-20152016,6,13.html, 2017 [In Polish].

5. AGNEW J., LAGUE C., SCHOENAU J., FEDDESM J., GUO H. Effect of manure type, application rate, and application method on odours from manure spreading. Can. Biosyst. Eng. 52, 6.19, 2010.

6. MIELCAREK P., RZEŹNIK W. Odor Emission Factors from Livestock Production. Pol. J. Environ. Stud. 24 (1), 27, 2015.

7. OIAMO T.H., LUGINAAH I.N., BAXTERUMU J. Cumulatlative effects of noise and odour annoyances on environmental and health related quality of life. Soc. Sci. Med. 146, 191, 2015.
8. WING S., HORTON R.A., MARSHALL S.W., THU K., TAIIK M., SCHINASI L. Air pollution and odor in communities near industrial swine operations. Environ. Health. Persp. 116 (10), 1362, 2008.

9. FEILBERG A., DORNO N., NYORD T. 2010. Odour emissions following land spreading of animal slurry assessed by proton-transfer-reaction mass spectrometry (PTRMS). Chem. Eng. Trans. 23, 111, 2010.

10. BRANDT R.C., ELLIOTT H.A., ADVIENTO-BORBE M.A.A., WHEELER E.F., KLEINMAN P.J.A., BEEGLE D.B. Field Olfactometry Assessment of Dairy Manure Land Application Methods. J. Environ. Qual. 40, 431, 2011.

11. KUNOWSKA-ŚLÓSARZ M., GURDAŁA J., GOŁĘBIEWSKI M., PRZYSUCHA T. Methods for reducing odor emissions in livestock buildings and their surroundings. Wiadomości Zootechniczne. LIV (1), 118, 2016 [In Polish].

12. TOKARCZYK-DOROCIAK K., KAZAK J., SZEWRAŃSKI S. The Impact of a Large City on Land Use in Suburban Area - the Case of Wrocław (Poland). J. Ecol. Eng. 19 (2), 89, 2018.

13. DUNCAN E.W., DELL C.J., KLEINMAN P.J.A., BEEGLE D.B. Nitrous Oxide and Ammonia Emissions from Injected and Broadcast-Applied Dairy Slurry. J. Environ. Qual. 46 (1), 36, 2017.

14. HANSEN M.N., SOMMER S.G., MADSEN N.P. Reduction of ammonia emission by shallow slurry injection: injection efficiency and additional energy demand. J. Environ. Qual. 32 (3), 1099, 2003.

15. DINUCCIO E., GIOELLI F., BALSARI P., DORNO N. Ammonia losses from the storage and application of raw and chemo-mechanically separated slurry. Agr. Ecosyst. Environ. 153, 16, 2012.

16. DELL C.J, MEISINGER J.J., BEEGLE D.B. Subsurface Application of Manures Slurries for Conservation Tillage and Pasture Soils and Their Impact on the Nitrogen Balance. J. Environ. Qual. 40, 352, 2011.

17. POTE D.H., MEISINGER J.J. Effect of poultry litter application method on ammonia volatilization from a conservation tillage system. J. Soil Water Conserv. 69 (1), 17, 2014.

18. PERSONNE E., TARDY F., GÉNERMONT S., DECUQ C., GUEUDET J.-C., MASCHER N., DURAND B., MASSON S., LAURANSOT M., FLÉCHARD C., BURKHARDT J., LOUBET B. Investigating sources and sinks for ammonia exchanges between the atmosphere and a wheat canopy following slurry application with trailing hose. Agric. For. Meteorol. 207, 11, 2015.

19. HÄNI C., SINTERMANN J., KUPPER T., JOCHER M., NEFTEL A. Ammonia emission after slurry application to grassland in Switzerland. Atmos. Environ. 125, 92, 2016.

20. DÖHLER H., VANDRÉ R., RÖßLER R., WULF S. Ammonia emissions: Abatement costs for the application of liquid manure. Landtechnik 66 (6), 469, 2011.

21. PAIN B.F., CLARKSON C.R., PHILLIPS V.R., KLARENBEEK J.V., MISSELBROOK T.H., BRUINS M. Odour emission arising from application of livestock slurries on land: Measurements following spreading using a micrometeorological technique and olfactometry. Journal of Agricultural Engineering Research, 48, 101, 1991.

22. HANNA H.M., BUNDY D.S., LORIMOR J.C., MICKELSON S.K., MELVIN S.W., ERBACH D.C. Manure incorporation equipment effects on odor, residue cover, and crop yield. Appl. Eng. Agric. 16, 621, 2000.

23. PARKER D.B., GILLEY J., WOODBURY B., KI-HYUN KIM, GALVIN G., BARTELT-HUNT S.L., LI X., SNOW 
D.D. Odorous VOC emission following land application of swine manure slurry. Atmos. Environ. 66, 91, 2013.

24. MIELCAREK P., RZEŹNIK W., ZBYTEK Z. 2017. The effect of solid manure incorporation into the soil on the emission of gases and odours. Proceedings of the $8^{\text {th }}$ International Scientific Conference Rural Development 2017, ISSN 1822-3230 / eISSN 2345-0916; s. 669-673.

25. BARTKOWIAK A., JADCZYSZYN T., MAC J., MATROS B., MATYKA M., MIELCAREK P., RZEŹNIK W., STEKLA J., TALARCZYK W., ZBYTEK Z., WITOROŻEC A. 2017. Różne aspekty wykorzystania masy pofermentacyjnej. Red. Nauk. W. Rzeźnik. Wyd. ITP, Falenty-Poznań. ISBN 978-83-65426-31-4. ss. 109.

26. FEILBERG A., LIU D., NYORD T. Temporal Variation in Odorant Composition Following Land Application of Manure. Chem. Eng. Trans. 40, 55, 2014.

27. HELLSTEDT M., HAAPALA H. Using a new finnish environmental technology to reduce odour emissions from manure storage and spreading. 25th Congress "Nordic View To Sustainable Rural Development", 260, 2015.

28. SMITH E., GORDON R., CAMPBELL A., BOURQUE C.P.A. An assessment of odour emissions from land applied swine manure, Can. Biosyst. Eng. 49, 6.33, 2007.

29. CHEN L., GRAY C.W., NEIBLING H., YADANAPARTHI S.K.R. On-farm comparison of two dairy manure application methods in terms of ammonia and odor emissions and costs. Appl. Eng. Agric. 30 (5), 805, 2014.

30. CHEN Y., ZHANG Q., PETKAU D.S. Evaluation of different techniques for liquid manure application on grassland. Appl. Eng. Agric. 17 (4), 489, 2001.

31. ORZI V., RIVA C., SCAGLIA B., D'IMPORZANO G., TAMBONE F., ADANI F. Anaerobic digestion coupled with digestate injection reduced odour emissions from soil during manure distribution. Sci. Total Environ. 621, 168, 2018.

32. LAU A., BITTMAN S., LEMUS G. Odor measurements for manure spreading using a subsurface deposition applicator. J. Environ. Sci. Health. 38, 233, 2003.

33. MOSELEY P.J., MISSELBROOK T.H., PAIN B.F., EARL R., GODWIN R.J. The Effect of Injector Tine Design on Odour and Ammonia Emissions following Injection of Bio-solids into Arable Cropping. J. Agr. Eng. Res. 71, 385, 1998.

34. RIVA C., ORZI V., CAROZZI M., ACUTIS M., BOCCASILE G., LONATI S., TAMBONE F., D'IMPORZANO G., ADANI F. Short-term experiments in using digestate products as substitutes for mineral $(\mathrm{N})$ fertilizer: Agronomic performance, odours, and ammonia emission impacts. Sci. Total Environ. 547, 206, 2016. 
